\title{
Mineralization of galena in an aplitic albitite from carbonatite complex of Tiruppattur, Tamil Nadu, India
}

\author{
R. Ramasamy, SP. Subramanian and R. Sundaravadivelu \\ 1,2,3 (Department of Ocean Engineering, Indian Institute of Technology-Madras, Chennai, 600036 India)
}

\begin{abstract}
A 10cmx10cmx10cm galena and associate albite from an aplitic albitite vein cutting across a skarn rock, near Garigaipalli village, in the carbonatite complex of Tiruppattur, Tamil Nadu, India were collected and studied for systematic variations in chemical composition from the central portions to outer peripheries. The compositions of albite grains show a linear trend of crystallizations from $\mathrm{Ne}_{81} \mathrm{Ks}_{0} Q_{z_{29}}$ to $\mathrm{Ne}_{48} \mathrm{Ks} s_{0} \mathrm{Qz}_{52}$. Covariation diagrams of $\mathrm{Pb}-\mathrm{S}, \mathrm{Na} \mathrm{a}_{2} \mathrm{O}-\mathrm{PbO},(\mathrm{Ca}+\mathrm{Na}+\mathrm{K})-\left(\mathrm{Si}+\mathrm{Ti}+\mathrm{Al}^{+3}\right)$ and $(\mathrm{Ca}+\mathrm{Na}+\mathrm{K})-\mathrm{S}$ show sequences of crystallizations of albite and galena with miscibility gaps between them. These components in albite and galena negatively vary in opposite directions in these diagrams. Galena mineralization might have been initiated just after immiscible separation of sulphide phases from silicate phases but prior to initial crystallization of albite Tf3 at higher temperature. During the course of crystal growths under the influence of crystal field stabilization forces, mixed pattern of arrangement of individual early formed and late formed microcrystals together was taken place. Incorporations of volatiles into the voids of subsolidus crystal originated pits of galena and albite, play critical role on the increase of viscosity of residual magma and it depends upon the rate of cooling. Progressive depletion of $\mathrm{Al}, \mathrm{Na}, \mathrm{K}$ and $\mathrm{S}$ contents in sequentially crystallized albite and galena indicates that residual magma was enriched with these constituents and Si. After this co-magmatic differentiation the residual magma fractionated into silica oversaturated granitic magma as end product.
\end{abstract}

Keywords: Albite, Galena, Albitite, Carbonatite complex of Tiruppattur, Crystal field stabilization, Crystal imperfections

\section{INTRODUCTION}

Carbonatite complexes are generally associated with mineralization of apatite, vermiculite, zircon, magnetite, REE minerals, and sulphides of molybdenum, lead, zinc and copper [1]. The zoned carbonatite complex of Tiruppattur $\left(12^{\circ} 15^{\prime}-12^{\circ} 30^{\prime} \mathrm{N}\right.$ : $\left.78^{\circ} 25^{\prime}-78^{\circ} 35^{\prime} \mathrm{E}\right)$, Tamil Nadu [2-4] is comprised with series of comagmatic soda-rich and potash rich alkali syenites emplaced in sequential order in two adjacent structural basins with magmatic continuity [2-4]. This carbonatite complex is not an exception to this observation. It is associated with mineralization of vermiculite, a large quantity of ultra-potassic feldspar, wollastonite, nioborutile, apatite, zircon, pyrochlore, Ba-Sr enriched carbonates, barite-quartz deposits [5] and a reserve of 5-6 million tones molybdenum bearing poly-metallic sulphide of ore with Mo percentage of $0.07 \%$ [6,7]. The carbonatite complex of Tiruppattur encloses carbonatites of Sevvattur (Korati, Karappattu), Jogipatti (Samalpatti) and Onnakarai (Samalpatti, Garigaipalli, Pallasulakkarai, Mottusulakkarai and Olaipatti). Onnakarai carbonatite is enclosed in a large arcuate shaped ultramafic body [2-4]. A spherical pod form galena more than $10 \mathrm{~cm}$ in size was collected from a thin vein-let $(5 \mathrm{mx} 0.5 \mathrm{~m})$ of pink coloured aplitic albitite crosscutting the skarn rock at the contact of ultramafic body. Ultrabasic nodules present in the skarn rock of Garigaipalli, are also composed of disseminations native copper, copper sulphides, azurite, malachite, pyrite, pyrrhotite and galena $(\mathrm{PbS})[8]$.

\section{FIELD RELATIONSHIP}

Co-magmatic carbonatites and alkali syenites sequentially emplaced in two adjacent structural basins bounded by steep fault planes [3,4,9-14] in a graben structure called Alangayam rift valley trending in NE-SW directions lying between Elagiri Hill and Javadi Hills [10]. The rift valley is also dissected by N-S, E-W and NW-SE trending fault planes. Magmatic emplacements, displacement of rock bodies, lithological units with sharp contacts, slicken-sides and occurrences of basalt-like dark mylonitic granitic gneisses are evidences for these fault movements. However, most magmatic bodies are highly differentiated and fractionated at depth and exhibits magmatic zonal variations between various types of alkali syenites, carbonatites, pegmatites and aplites. These magmatic rocks were differentiated under prolonged period of fractional crystallization within a subjacent closed magmatic chamber [3-6; 9-15]. Differentiated and fractionated magmatic bodies in a closed magmatic chamber at depth sequentially emplaced first in the northern Sevvattur basin and subsequently with tectonic disturbance in southern Jogipatti basin [3]. The magmatic rocks occurring in both these basins show magmatic continuity and are co-magmatic in nature but, the magmatic series occurring in the southern Jogipatti basin appear to be younger to the magmatic rock series occurring in Sevvattur basin. The northern Sevvattur body 
shows irregular zonation and is comprised of cone-sheets of carbonatite body with a core of beforsite. Immediately south of the cone-sheets of carbonatite, an outer shell of speckled hornblende syenite is seen in the northern portion $[4,12,15]$. This is followed by a mottled porphyritic augite syenite which grades into a mottled augite syenite along its peripheral portions. The core portion of the body is occupied by oligoclasite and albitite. A carbonatite body crops out along the contact between ultramafic rock and the syenites in the northern periphery of the body. The ultamafic rocks are essentially composed of pyroxenites and by intrusions of thin veins of oligoclasites, albitites and carbonatites in pyroxenite which transformed into mica-pyroxenites and hornblende-oligoclase-calcite bearing pyroxenite. The Jogipatti body with inward dips is composed of riebeckite syenite which grades into melanite-orthoclase syenite, melanite-microcline ultrapotassic syenite [4, 12, 15 ], wollastonite-melanite syenite, wollastonite-rock and melanite-wollastonite sovite. At the contact between melanite-wollastonite syenite and melanite-wollastonite sovite, scapolite-wollastonite syenite is developed. In this Jogipatti basin [4], carbonatite occurs as ring dykes and veins in the riebeckite syenite and veins and breccias at the contact between ultramafic rocks and syenites [11]. The degree of fractionation is so extensive; agpaitic rocks and ultrapotassic syenites are emplaced within this complex. Both high field strength elements $(\mathrm{K}, \mathrm{Ba}, \mathrm{Sr}, \mathrm{Ti}, \mathrm{P})$ and incompatible elements $(\mathrm{Zr}, \mathrm{Hf}, \mathrm{Nb}, \mathrm{Ta}, \mathrm{Y}, \mathrm{Sc})$ concentrate in late magmatic fluids. After reaching required concentrations $[15,16]$ of these elements, they form as discrete minerals of their own in residual magma. The peripheral portion of the galena sample collected is associated with well developed prismatic crystals of pyromorphite and wulframite of sizes varying from $1 \mathrm{~mm}$ up to $5 \mathrm{~mm}$. The galena exhibits cubic cleavage and metallic luster. It is very dense and has a density around $7.5 \mathrm{gm} / \mathrm{cc}$. The streak of the galena is lead-grey. Galena also occurs as disseminations in albitite and in ultramafic nodules occurring in the skarn rock. The skarn rock exhibits two or three generations of plastic fold patterns and the ultramafic nodules occur along these micro-fold axial planes. Most of these ultramafic nodules are carbonatized towards the NE direction from Onnakarai village where, incipient development of carbonates in ultramafic nodules is seen. The dimensions of these nodules vary from $<1 \mathrm{~cm}$ to $>30 \mathrm{~cm}$. Within these nodules, alternate calcite veins of 1 to 2 $\mathrm{mm}$ thickness show imbricate superimposed plastic fold-pattern of two or three generations and these features are seen even in hand specimens. Along tightly folded axial planes of these nodules grossularite-andradite garnet occurs. Disseminations of pyrite, chalcopyrite, galena, covellite, bornite, native copper, azurite and malachite are seen in these nodules preserved in the tightly superimposed antiform-folded axial planes. On the other hand nodules aligned along synformly superimposed folded axial plane consisting of wollastonite and calcite are manifested without any significant concentration of sulphide minerals. The field relationship indicates that the skarn rock is formed along the contact between ultramafic rocks and garnetiferous orthoclase syenite $[4,12,15]$. Thin veins (in the range of $5-50 \mathrm{~cm}$ ) of ankeritic and sovite carbonatites are also found within this skarn rock. The ultramafic rock exhibits kimberlitic affinity [14]. Forceful injections of syenites and carbonatites along the contact of ultramafic rock might have mobilized the latter into skarn rock by hot fluids emanated from these igneous bodies. Along the contacts of the skarn rock, mineralization of polymetallic sulphides of copper, iron and lead including chalcopyrite, pyrite and galena and other minerals like monazite, riebeckite, wollastonite, barite, apatite and niobo-rutile is found. Along the contact of syenite with ultramafic body, extensive development of biotite is seen in the ultramafic rock. Sulphide minerals are extensively developed along joint planes, shear zones and gneissic and schistose planes of the ultramafic rock altered to biotite bearing amphibolite along the contact of syenite body. The amphibolite is enriched with sulphide minerals with concentration of silver up to a maximum of $40 \mathrm{ppm} . \mathrm{SO}_{3}$ content increases up to $1.75 \%$ (wt/\%) in amphibole and biotite rich ultramafic rocks. Along the shear zones, the ultramafic body which is essentially composed of calcium bearing pyroxene is extensively transformed into riebeckite veins and developments of pods and pockets of calcite are also seen. Crocidolite mineralization is seen in association with beforsite carbonatite veins at about $500 \mathrm{~m} \mathrm{WNW}$ of Mottusulakkarai village. Veins of apatite-ilmenorutile are found about $500 \mathrm{~m} \mathrm{NE}$ of Pallasulakkarai village. Barite-calcite mineralization is found $100 \mathrm{~m}$ south of Onnakarai village. The Jogipatti-carbonatite contains 0.17 to $1.73 \%$ wt $\mathrm{SO}_{3}$. Benstonite bearing carbonatite veins are also exposed in this area. The syenite around this carbonatite contains scapolite associated with acmite, diopside, garnet and wollastonite. Wollastonite and scapolite bearing aegirine syenites and riebeckite veins contain up to $1.5 \%$ (wt.) of $\mathrm{SO}_{3}$. All these features indicate that parent magma from which late magmatic alkali syenites and carbonatites were separated by immiscible fractions silicate-carbonate phases and silicate-sulphide phases might have enriched with significant amount of $\mathrm{CO}_{2}$ and $\mathrm{SO}_{3}$ in their compositions.

\section{METHODOLOGY}

In order to study the mineralization, a single fragment of galena ( $2 \mathrm{~mm} \times 2 \mathrm{~mm} \times 1 \mathrm{~mm})$ and a fragment of albitite (2 $\mathrm{mm} \times 2 \mathrm{~mm} \times 1 \mathrm{~mm})$ are subjected to "High Resolution EDAX" probe analyses in the Department of Material and Metallurgical Engineering, Indian Institute of Technology Madras, Chennai. Eight EDAX (Energy Diffusive X-ray micro- analyses) analyses were made systematically on feldspar at different points from its center to periphery. Four EDAX analyses were carried out from the fragment of a pure galena, on different 
Mineralization of galena in an aplitic albitite from carbonatite complex of Tiruppattur, Tamil Nadu,

points of galena at a magnification of 5000x. Counts versus electron energy levels of elements are measured (SEM Images in Figure. 2). Trace element concentrations of these minerals are also detected with the help of EDAX probe analyzer. They represent the chemical composition at the site of cursor positions where the electron diffusive micro analysis is made (EDAX images Plate 1 and 2). The original analyses are presented (Figure 3). The major elements are recalculated into their oxide forms. Feldspars are re-calculated on the basis of $32(\mathrm{O})$ to derive their structural formulae (Table 1). Only total iron is reported in the form of $\mathrm{FeO} . \mathrm{H}_{2} \mathrm{O}$ and other volatiles like $\mathrm{CO}_{2}, \mathrm{CH}_{4}$ etc. are not determined. Hence the contents of moisture and loss of ignition are not given.

\section{RESULTS}

Pure galena is composed with $\mathrm{Pb} 86.6 \%$ and $\mathrm{S} 13.4 \%$. The $\mathrm{Pb}$ content in the analyzed galena crystals varies from 67.31 to $75.65 \%$ and $\mathrm{S}$ from 12.71 to $17.22 \%$ (Table 1). This may be due to small amounts of substitutions [17] of $\mathrm{Sb}, \mathrm{As}, \mathrm{Bi}, \mathrm{Ag}, \mathrm{Tl}, \mathrm{Cd}, \mathrm{Co}$ and $\mathrm{Ni}$ which were not detected in these analyses. However substitutions of $\mathrm{Zn}$ and $\mathrm{Cu}$ are estimated. The galena $(\mathrm{PbS}), \mathrm{Pb}$ is replaced by other elements from 10.95 to $19.29 \%$. Presence of significant amount of $\mathrm{Nb}$ is detected; however, $\mathrm{Nb}$ sulphides are rare. During calculation of Rittmann's norm, considerable amounts of $\mathrm{Fe}$, $\mathrm{Ti}$ and $\mathrm{Na}$ are allotted for the formation of pyrochlore and villamaninite to accommodate excessive sulphide ions (Table 2). The chemical compositions indicate that $\mathrm{SiO}_{2}$ contents widely vary between $53.84 \%$ (Tf3) to $73.42 \%$ (Tf5) with a mean value of $62.61 \% \mathrm{SiO}_{2}, \mathrm{Al}_{2} \mathrm{O}_{3} 20.90 \%$, $\mathrm{Na}_{2} \mathrm{O} 12.23 \%$ and $\mathrm{K}_{2} \mathrm{O} 0.81 \%$ indicating composition of an albite mineral. The silica poor feldspars have typically enriched with a high content of alumina (24\%) and soda (16\%). Except Tf5, all other feldspars are nepheline normative up to a maximum of $48.92 \%$ (wt. \%). The structural formulae calculated on the basis of $32(\mathrm{O})$ show that all of them belong to albite. On comparison with nepheline structural formula on the basis of $32(\mathrm{O})$, they have high $\mathrm{Si}$ above 8 in tetrahedral site, low in six fold co-ordination (3.26-4.52 i.e. $<8$ ions) and octahedral coordination (2.63-6.14 i.e. $<8$ ions). Therefore, all of them belong to albite only. Si ions in tetrahedral sites are deficient in all albite grains, except Tf5 which is the only albite saturated with Si in that site. On the other hand, Tf5 is enriched in $\mathrm{Si}$ in its tetrahedral site, it greatly deficient in hexahedral site $(\mathrm{Al}=3.08<$ 4). This deficiency could not be compensated by entry of Fe, Mn and $\mathrm{Ti}(3.261<4)$. Further it is highly deficient in X-site instead of 4 it has hardly 2.63 ions. In all albites, Z-site is very close to 16 ions. Si has 12 ions in tetrahedral site under normal state. In order to meet silica deficiencies in the tetrahedral site $\mathrm{Ti}^{+4}$ enters into the lattice. Under insufficient $\mathrm{Ti}^{+4}, \mathrm{Al}^{+3}$ enters into the lattice. Though albites of $\mathrm{Tf} 3$ and $\mathrm{Tf} 2$ are highly deficient in tetrahedral $\mathrm{Si}$, their silica deficiencies are respectively compensated by entries of $\mathrm{Al}^{+3}$ ions of 1.976 and 1.427 ions. All the feldspars have significant amount of $\mathrm{Al}^{+6}$ however in addition to $\mathrm{Fe}^{2}, \mathrm{Mn}, \mathrm{Mg}$ only 4 feldspars (Tf3, Tf7, Tf8 and Tf4) have sufficient ions of hexa-fold coordination and the rest (Tf2, Tf1, Tf6, Tf5) have insufficient ions in their lattices. These features indicate that albites enriched with $\mathrm{Al}^{+3}$ ions were initiated subsolidus highly disordered state of crystallization at high temperature condition. Entry of normative nepheline molecules is possible in $\mathrm{Si}$ deficient albites enriched with $\mathrm{Na}$ and $\mathrm{Al}$ ions. In these albites, $\mathrm{X}$-site is oversaturated with lime and alkali elements and it is above 4 in most of the feldspars. The Si deficiencies in tetrahedral sites and enrichments in $\mathrm{Al}$ in $\mathrm{Z}$ lattices in most albites indicate substitution of considerable amount of normative nepheline to a maximum of $\mathrm{Ne}_{53} \mathrm{Ab}_{47}$ in sample Tf3. On the other hand silica saturated albite presents with $\mathrm{qz}_{21} \mathrm{Ab}_{79}$ in the sample Tf5. The eight albite crystals analyzed from an albitite fragment show continuous chemical and mineralogical compositional normative proportions from silica undersaturated state to silica oversaturated end. The normative proportions of 8 albites are plotted in a trilinear diagram of $\mathrm{NaAlSiO}_{4}{ }^{-}$ $\mathrm{KAlSiO}_{4}-\mathrm{SiO}_{2}$ system [18] at a $\mathrm{P}_{\mathrm{H} 2 \mathrm{O}}=5 \mathrm{~kb}$. It is reported that in this system if $\mathrm{P}_{\mathrm{H} 2 \mathrm{O}}$ increases over $5 \mathrm{~kb}$ and above, leucite field shrinks and albite field expands [17]. From this diagram (Figure 1) it is inferred that albite Tf3 $\left(\mathrm{Ne}_{81} \mathrm{Ks}_{0} \mathrm{Qz}_{19}\right)$ might have included into albite field at about $750^{\circ} \mathrm{C}$ and above $5 \mathrm{~kb} \mathrm{P}_{\mathrm{H} 2 \mathrm{O}}$. In all these feldspars potash content is limited.

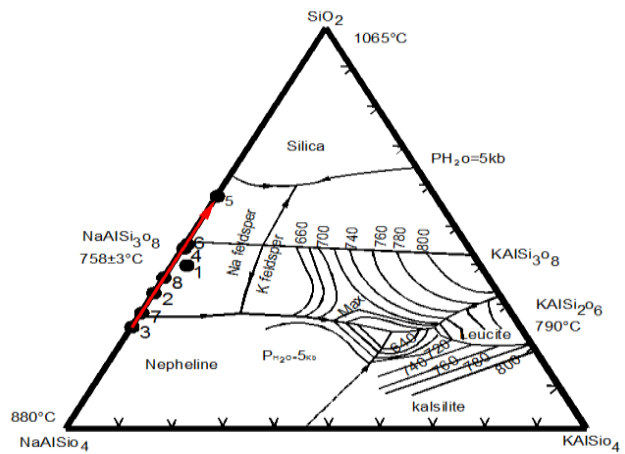

Figure 1 shows plot of normative proportions of Ne-Ks-Qz in the system $\mathrm{NeAlSiO}_{4}-\mathrm{KAISiO}_{4}-\mathrm{SiO}_{2} \mathrm{system}$ under $\mathrm{PH}_{2} \mathrm{O} 5$ kbar constructed by Zeng and Mackenzie 1984 [18]. 
Albite Tfl contains maximum of $3 \%$ of normative kalsilite. A differentiation trend moves from nepheline normative albite to silica saturated albite along Ne-Qz join from high temperature crystallization to low temperature albitic end (Fig. 1). Rittmann's silica saturated norm is calculated by distributing number of Si' atoms among silica saturated silicates without regard to available amount of $\mathrm{Si}$. In the equation $\mathrm{Dq}=\mathrm{Si}-\mathrm{Si}$ '; if $\mathrm{Dq}$ is positive in sign, the rock is oversaturated; if Dq is negative in sign, it is reported as such to indicate a silica deficiency. A negative value $\mathrm{Dq}$ is seen for all albite grains [18] except albite Tf5 grain (Table 2). The compositions of feldspars vary from $\mathrm{Or}_{28} \mathrm{Ab}_{72} \mathrm{An}_{0}$ to $\mathrm{Or}_{1} \mathrm{Ab}_{91} \mathrm{An}_{8}$ and they all belong to mono-mineral phase of albite [17]. In silica undersaturated magma, albite may be converted partially or completely into normative nepheline [17]. Significant amount of subsolidus replacement of albite by nepheline, riebeckite and aegirine augite is seen in the Rittmann's norm [19]. Tf3 albite $\left(\mathrm{Ab}_{47} \mathrm{Ne}_{53}\right)$ has albite $44 \%$, nepheline 49\%, aegirine augite $4.89 \%$, melanite $1.08 \%$, magnetite $0.21 \%$, galena $0.41 \%$ and villamaninite $0.46 \%$ (Table 2 ). Under thin section, only albite is present and nepheline is totally absent. Studying geochemical variation of these minerals under magnification of 5000x will give valuable information on the crystallization of minerals in their spatial and temporal variations. From the study it is revealed that the highly silica deficient albite from Tf3 crystallized at earlier stage followed by the albites sequentially enriched with silica components in the order Tf7, Tf2, Tf8, Tf1, Tf4, Tf6 and Tf5. Though, these albites crystallize sequentially one by one during the course of time, they are not packed in a serial order according to their age. The albites formed both early formed and late formed are also packed together in the albitite fragment as per crystal field stabilization theory initially at the corners and edges, later at their flat crystal faces. Further turbulence and currents in the magmatic fluid from which they crystallize may disturb the sequential order of albite crystal packing in the albitite fragment. Similar features are applicable to galena fragment also. Crystal originated pits of galena square, triangular, and rectangular shapes are seen. Subsolidus galena might have incorporated significant amount of volatiles in these void spaces of crystal originated pits. Similarly, volatiles might have occupied in void spaces created by dislocation of substrate layers in albitite.

The rock under study is an albitite essentially composed of albite $(95 \%$ vol.) and with galena $(<1 \%$ vol.) and other accessories ( $<4 \%$ vol.). Logarithmic decrease of albite content with increasing normative galena indicates a characteristic trend of magmatic crystallization (Fig. 2a). Galena substitution increases from tf5 to tf3 to maximum and then crystallization of galena takes place as individual crystals. A positive correlation is noted between $\mathrm{S}$ and $\mathrm{Pb}$ ions in feldspars (Fig. 2b). Normative nepheline increases against decreasing albite content (Fig. 2c). A linear trend of crystallization with intermittent concentration of galena cations with depletion of silica saturation is seen during the course of mineralization of galena (Fig. 2d). Tf3 has crystallized at high temperature condition having higher amount of $\mathrm{Al}^{+3}$ ions in its tetrahedral site. This feature indicates that $\mathrm{Tf} 3$ is formed with highly disordered state. A linear trend of decreasing $\mathrm{Al}^{+3}$ ions have entered in subsequently crystallized albites with progressively increasing substitution of Si ions in their tetrahedral states is seen with a linear trend (Fig. 2e). The trend indicates that Tf3 albite crystallization initiated from high temperature disordered state and ends with crystallization of $\mathrm{Si}$ filled tetrahedral site possessed albite Tf5. In the phase diagram [19] of $\mathrm{Na}_{2} \mathrm{O}-\mathrm{PbO}-\mathrm{SiO}_{2}$, distributions of $\mathrm{Na}_{2} \mathrm{O}$ and $\mathrm{PbO}$ show a negative correlation trend for these albite and galena. About $1.26 \%$ of $\mathrm{PbO}$ and $23.65 \%$ of $\mathrm{Na}_{2} \mathrm{O}$ with $75.10 \%$ of $\mathrm{SiO}_{2}$ concentrate at the intermediate state leading to immiscible separation of silicate and sulphide liquids and galena mineralization (Fig, 2f).

Galena mineralization takes place following trend of negative correlation with enrichment of $\mathrm{Ca}+\mathrm{Na}+\mathrm{K}$ with depletion of $\mathrm{Si}+\mathrm{Ti}+\mathrm{Al}^{+3}$ ions (Fig. $2 \mathrm{~g}$ ) at late magmatic stages. Sequence of crystallization of albite and galena trends in opposite directions for these minerals and miscibility gab between silicate and sulphide phases is inferred. An immiscible separation sulphide and silicate phases might have developed just prior to the high temperature crystallization of albite Tf3 around $750^{\circ} \mathrm{C}$ and above $5 \mathrm{kbar}$ water pressure [19]. Similar feature is also illustrated in the Fig. $2 \mathrm{~h}$. Ratios of incompatible elements of $\mathrm{Nb} / \mathrm{Ta}$ against $\mathrm{Zr} / \mathrm{Hf}$ indicate prolonged period of magmatic differentiation with wide spectrum of a linear trend of variation (Fig. 2i). Galena is relatively enriched with heavy elements of $\mathrm{Cu}_{(250-160 \mathrm{ppm})}, \mathrm{Zn}_{(840-230 \mathrm{ppm})}, \mathrm{Yb}_{(1270-200 \mathrm{ppm})}, \mathrm{Y}_{(1220-940 \mathrm{ppm})}, \mathrm{Ta}_{(1280-180 \mathrm{ppm})}, \mathrm{Hf}_{(960-380}$ ppm), $\mathrm{Dy}_{(640-380 \mathrm{ppm},)} \mathrm{Lu}_{(1200-400 \mathrm{ppm})} \mathrm{F}_{(1060-630 \mathrm{ppm})}$ and $\mathrm{Cl}_{(1020-480 \mathrm{ppm})}$. On the other hand albite is concentrated with $\mathrm{Zr}_{(90-130 \mathrm{ppm})}, \mathrm{Nb}_{(210-340 \mathrm{ppm})}, \mathrm{La}(90-510 \mathrm{ppm}), \mathrm{Ce}_{(80-470 \mathrm{ppm})}, \mathrm{Nd}_{(90-350 \mathrm{ppm})}, \mathrm{Eu}_{(120-380 \mathrm{ppm})}$ and $\mathrm{F}_{(190-700 \mathrm{ppm})}$ and $\mathrm{Cl}_{(50-220 \mathrm{ppm})}$. High ratios of $\mathrm{Zn} / \mathrm{Cu}$. $\mathrm{Co} / \mathrm{Ni}, \mathrm{Pb} / \mathrm{Cu}, \mathrm{Zr} / \mathrm{Hf}$ and $\mathrm{Nb} / \mathrm{Ta}$ in galena relative to albite indicate concentrations of $\mathrm{Zn}$, $\mathrm{Co}, \mathrm{Pb}, \mathrm{Zr}$, and $\mathrm{Nb}$ in late magmatic residual fluids. On the other hand concentrations of $\mathrm{F}$, La and $\mathrm{Ce}$ in residual albitic fluids are characteristic features for carbonatite complexes (Fig. 2j). Though EDAX analyses were made systematically from the centre to periphery, chemical compositions distinctly vary from their neighbouring ones but collectively they show linear variations. During crystal growth, packing individual grains of early formed with late formed together by turbulent swirling currents in magmatic fluids might be caused for these variations. Crystal growths along edges and solidangles are faster than the growths on flat surfaces and nucleation of early formed and late formed minerals together on the basis of crystal field stabilization forces might be additional cause. 
Table 1 Chemical composition of albite and galena (Tg1-Tg4 Galena; Tf1-Tf8 Albite)

\begin{tabular}{|c|c|c|c|c|c|c|c|c|c|c|c|c|}
\hline & $\operatorname{tg} 1$ & $\operatorname{tg} 2$ & $\operatorname{tg} 3$ & & & to & & $\mathrm{t}$ & tf5 & tf6 & f7 & 10 \\
\hline $\mathrm{SiO} 2$ & 1.38 & 1.21 & 1.51 & 1.27 & 60.44 & 57.55 & 53.84 & 63.19 & 73.42 & 65.04 & 63.62 & 63.75 \\
\hline $\mathrm{Al} 2 \mathrm{O} 3$ & 0.61 & 0.19 & 0.47 & 0.24 & 20.14 & 23.61 & 24.45 & 21.45 & 15.07 & 19.12 & 21.75 & 21.60 \\
\hline $\mathrm{FeO}$ & 0.95 & 0.37 & 0.50 & 0.25 & 0.52 & 0.35 & 0.37 & 0.52 & 0.29 & 0.28 & 0.31 & 0.28 \\
\hline $\mathrm{MnO}$ & 0.31 & 0.55 & 0.16 & 0.33 & 0.36 & 0.16 & 0.21 & 0.16 & 0.18 & 0.10 & 0.17 & 0.25 \\
\hline $\mathrm{MgO}$ & 0.49 & 0.17 & 0.37 & 0.37 & 0.21 & 0.41 & 1.93 & 1.02 & 0.42 & 0.18 & 0.44 & 0.11 \\
\hline $\mathrm{CaO}$ & 0.41 & 0.00 & 0.00 & 0.13 & 0.39 & 0.21 & 0.50 & 0.47 & 0.33 & 0.24 & 0.78 & 0.35 \\
\hline $\mathrm{Na} 2 \mathrm{O}$ & 0.34 & 0.24 & 0.25 & 0.00 & 10.55 & 16.28 & 16.53 & 9.72 & 7.41 & 13.37 & 12.32 & 11.70 \\
\hline K2O & 0.52 & 0.00 & 0.00 & 0.14 & 4.22 & 0.33 & 0.43 & 0.53 & 0.35 & 0.21 & 0.13 & 0.26 \\
\hline $\mathrm{TiO} 2$ & 0.45 & 0.00 & 0.00 & 0.19 & 0.44 & 0.29 & 0.27 & 0.21 & 0.29 & 0.00 & 0.04 & 0.34 \\
\hline S & 12.77 & 13.73 & 17.22 & 12.17 & 0.13 & 0.07 & 0.32 & 0.15 & 0.14 & 0.12 & 0.11 & 0.11 \\
\hline $\mathrm{Nb} 2 \mathrm{O} 5$ & 6.45 & 9.44 & 5.68 & 3.05 & 0.76 & 0.00 & 0.00 & 0.64 & 0.00 & 0.00 & 0.00 & 0.00 \\
\hline $\mathrm{ZnO}$ & 0.39 & 1.31 & 0.72 & 0.00 & 0.00 & 0.00 & 0.00 & 0.00 & 1.80 & 0.85 & 0.00 & 0.00 \\
\hline $\mathrm{CuO}$ & 0.42 & 0.28 & 0.25 & 0.36 & 0.35 & 0.00 & 0.24 & 0.19 & 0.06 & 0.00 & 0.03 & 0.17 \\
\hline \multirow[t]{2}{*}{$\mathrm{PbO}$} & 74.51 & 72.51 & 72.85 & 81.50 & 1.48 & 0.75 & 0.91 & 1.75 & 0.24 & 0.48 & 0.31 & 1.07 \\
\hline & 100 & 100 & 100 & 100 & 100 & 100 & 100 & 100 & 100 & 100 & 100 & 100 \\
\hline $\mathrm{Si}$ & 0.746 & 0.633 & 0.750 & 0.767 & 11.159 & 10.533 & 9.986 & 11.325 & 12.743 & 11.641 & 11.313 & 11.375 \\
\hline $\mathrm{Al}$ & 0.388 & 0.117 & 0.279 & 0.173 & 4.383 & 5.096 & 5.346 & 4.533 & 3.085 & 4.035 & 4.561 & 4.544 \\
\hline $\mathrm{Fe}$ & 0.430 & 0.163 & 0.209 & 0.125 & 0.081 & 0.054 & 0.058 & 0.077 & 0.042 & 0.041 & 0.045 & 0.042 \\
\hline Mn & 0.143 & 0.245 & 0.068 & 0.169 & 0.057 & 0.025 & 0.033 & 0.025 & 0.026 & 0.016 & 0.026 & 0.038 \\
\hline $\mathrm{Mg}$ & 0.395 & 0.130 & 0.279 & 0.335 & 0.057 & 0.112 & 0.534 & 0.272 & 0.108 & 0.048 & 0.116 & 0.030 \\
\hline $\mathrm{Ca}$ & 0.239 & 0.000 & 0.000 & 0.087 & 0.078 & 0.041 & 0.099 & 0.091 & 0.062 & 0.047 & 0.148 & 0.066 \\
\hline $\mathrm{Na}$ & 0.361 & 0.241 & 0.245 & 0.000 & 3.777 & 5.776 & 5.942 & 3.376 & 2.492 & 4.639 & 4.246 & 4.048 \\
\hline K & 0.357 & 0.000 & 0.000 & 0.104 & 0.993 & 0.077 & 0.101 & 0.122 & 0.077 & 0.048 & 0.029 & 0.060 \\
\hline $\mathrm{Ti}$ & 0.182 & 0.000 & 0.000 & 0.085 & 0.062 & 0.040 & 0.038 & 0.029 & 0.038 & 0.000 & 0.006 & 0.046 \\
\hline $\mathrm{Si}+\mathrm{Ti}+\mathrm{Al}$ & 1.316 & 0.751 & 1.029 & 1.024 & 15.604 & 15.669 & 15.369 & 15.886 & 15.866 & 15.676 & 15.880 & 15.965 \\
\hline $\mathrm{X}$ & 0.957 & 0.241 & 0.245 & 0.191 & 4.848 & 5.893 & 6.142 & 3.590 & 2.631 & 4.734 & 4.423 & 4.175 \\
\hline S & 12.91 & 13.48 & 16.08 & 13.78 & 0.04 & 0.03 & 0.11 & 0.05 & 0.04 & 0.04 & 0.04 & 0.04 \\
\hline $\mathrm{Nb}$ & 1.57 & 2.23 & 1.28 & 0.83 & 0.06 & 0.00 & 0.00 & 0.05 & 0.00 & 0.00 & 0.00 & 0.00 \\
\hline $\mathrm{Zn}$ & 0.15 & 0.51 & 0.26 & 0.00 & 0.00 & 0.00 & 0.00 & 0.00 & 0.23 & 0.11 & 0.00 & 0.00 \\
\hline $\mathrm{Cu}$ & 0.17 & 0.11 & 0.09 & 0.16 & 0.05 & 0.00 & 0.03 & 0.03 & 0.01 & 0.00 & 0.00 & 0.02 \\
\hline $\mathrm{Pb}$ & 10.83 & 10.22 & 9.77 & 13.25 & 0.07 & 0.04 & 0.05 & 0.08 & 0.01 & 0.02 & 0.01 & 0.05 \\
\hline $\mathrm{F} / \mathrm{Cl}$ & 0.62 & 1.74 & 0.00 & 0.00 & 0.00 & 0.00 & 5.00 & 1.27 & 0.00 & 3.00 & 4.71 & 0.00 \\
\hline $\mathrm{Y} / \mathrm{Sc}$ & 0.36 & 0.29 & 0.43 & 0.71 & $1.09 \mathrm{nd}$ & nd & & $5.52 \mathrm{nd}$ & nd & nd & nd & \\
\hline $\mathrm{La} / \mathrm{Lu}$ & 0.79 & 0.48 & 0.00 & 0.85 & 1.24 & 0.75 & 0.27 & 0.86 & 1.42 & 0.67 & 0.31 & 1.06 \\
\hline $\mathrm{Ce} / \mathrm{Yb}$ & 0.62 & 1.45 & 0.00 & 1.50 & 0.78 & 0.66 & 0.25 & 0.42 & 1.11 & 1.13 & 0.83 & 0.65 \\
\hline $\mathrm{Yb} / \mathrm{Ta}$ & 0.99 & 0.25 & 0.18 & 1.56 & 1.22 & 1.16 & 1.23 & 1.13 & 0.62 & 1.23 & 0.66 & 1.26 \\
\hline $\mathrm{Zr} / \mathrm{Hf}$ & 1.04 & $1.39 \mathrm{nd}$ & & 1.97 & 0.45 & 0.00 & 0.00 & 0.00 & $0.42 \mathrm{nd}$ & & 0.00 & 0.36 \\
\hline $\mathrm{Zn} / \mathrm{Cu}$ & 0.92 & 4.67 & 2.88 & 0.00 & $0.00 \mathrm{nd}$ & & 0.00 & 0.00 & $28.75 \mathrm{nd}$ & & 0.00 & 0.00 \\
\hline $\mathrm{Nb} / \mathrm{Ta}$ & 2.62 & 6.48 & 2.77 & 7.39 & 0.69 & 0.00 & 0.00 & 0.45 & 0.00 & 0.00 & 0.00 & 0.00 \\
\hline $\mathrm{Al} / \mathrm{Si}$ & 0.50 & 0.18 & 0.36 & 0.22 & 0.38 & 0.46 & 0.51 & 0.38 & 0.23 & 0.33 & 0.39 & 0.38 \\
\hline $\mathrm{Co} / \mathrm{Ni}$ & 6.83 & 0.79 & 0.73 & $1.73 \mathrm{nd}$ & & & 0.11 & $0.49 \mathrm{nd}$ & & & nd & \\
\hline $\mathrm{Pb} / \mathrm{Cu}$ & 63.08 & 91.30 & 103.21 & 80.38 & $1.50 \mathrm{nd}$ & & 1.33 & 3.37 & $1.38 \mathrm{nd}$ & & 3.37 & 2.21 \\
\hline
\end{tabular}




\begin{tabular}{lrrrrrrrrrrrrr} 
& \multicolumn{1}{c}{ Table 2 Rittmann's normative proportions of EDAX Analyses (wt.\%) } \\
Mineral & \multicolumn{1}{c}{ Tg1 } & Tg2 & \multicolumn{1}{c}{ Tg3 } & \multicolumn{1}{c}{ Tg4 } & \multicolumn{1}{c}{ Tf1 } & \multicolumn{1}{c}{ Tf2 } & \multicolumn{1}{c}{ Tf3 } & Tf4 & Tf5 & Tf6 & \multicolumn{1}{c}{ Tf7 } & Tf8 \\
il & 0.00 & 0.00 & 0.00 & 0.00 & 0.00 & 0.07 & 0.21 & 0.33 & 0.46 & 0.16 & 0.00 & 0.39 \\
pc & 11.95 & 12.02 & 9.06 & 5.86 & 0.65 & 0.00 & 0.00 & 0.55 & 0.00 & 0.00 & 0.00 & 0.00 \\
ga & 79.81 & 79.75 & 83.29 & 89.13 & 0.44 & 0.14 & 0.41 & 0.55 & 0.12 & 0.21 & 0.17 & 0.34 \\
sp & 1.08 & 3.93 & 2.30 & 0.00 & 0.00 & 0.00 & 0.00 & 0.00 & 0.12 & 0.21 & 0.00 & 0.00 \\
vil & 1.91 & 1.35 & 1.15 & 1.71 & 0.00 & 0.00 & 0.46 & 0.00 & 0.17 & 0.00 & 0.06 & 0.00 \\
mt & 0.00 & 0.00 & 0.00 & 0.00 & 0.27 & 0.07 & 0.21 & 0.16 & 0.06 & 0.21 & 0.23 & 0.06 \\
ab & 2.27 & 0.00 & 0.00 & 0.00 & 80.43 & 61.04 & 43.87 & 75.63 & 73.03 & 93.41 & 49.24 & 74.25 \\
bi & 0.96 & 0.00 & 0.00 & 0.00 & 0.00 & 0.00 & 0.00 & 6.20 & 0.00 & 0.00 & 1.36 & 3.21 \\
cord & 0.84 & 0.00 & 0.00 & 1.59 & 0.00 & 0.00 & 0.00 & 0.00 & 3.82 & 0.00 & 0.00 & 0.00 \\
mus & 1.19 & 0.49 & 1.28 & 0.00 & 0.00 & 0.00 & 0.00 & 11.20 & 3.30 & 0.00 & 0.00 & 0.00 \\
cpx & 0.00 & 0.00 & 0.00 & 0.00 & 1.58 & 0.17 & 4.85 & 0.00 & 0.00 & 0.00 & 2.83 & 0.00 \\
spe & 0.00 & 0.00 & 0.00 & 0.00 & 0.00 & 0.00 & 0.00 & 0.00 & 0.00 & 0.32 & 0.00 & 0.00 \\
amp & 0.00 & 0.00 & 0.00 & 0.00 & 0.00 & 0.00 & 0.00 & 0.00 & 0.00 & 1.39 & 0.00 & 0.00 \\
mel & 0.00 & 0.00 & 0.00 & 0.00 & 0.00 & 0.69 & 1.08 & 0.00 & 0.00 & 0.00 & 0.62 & 0.00 \\
ne & 0.00 & 0.00 & 0.00 & 0.00 & 16.63 & 37.82 & 48.92 & 5.38 & 0.00 & 4.07 & 45.50 & 21.75 \\
qz & 0.00 & 2.45 & 2.93 & 1.71 & 0.00 & 0.00 & 0.00 & 0.00 & 18.92 & 0.00 & 0.00 & 0.00
\end{tabular}

Illustrations: il- ilmenite, pc -pyrochlore, ga-galena, sp-sphalerite, vil -villamaninite, mt- magnetite, ab- albite, bi-biotite, cord-cordierite, mus -muscovite, cpx - augite, spe- sphene, amp- hornblende, mel-melanite, nenepheline, qz- quartz

\section{DISCUSSION}

The carbonatite complex of Tiruppattur is associated with comagmatic soda and potash rich alkali syenites $[4,12,15]$. They are enriched with $\mathrm{SO}_{3}, \mathrm{P}_{2} \mathrm{O}_{5}, \mathrm{CO}_{2}, \mathrm{~F}, \mathrm{Cl}, \mathrm{O}_{2}$ and $\mathrm{H}_{2} \mathrm{O}$. The syenites widely vary in composition from highly silica undersaturated to oversaturated end. Silica undersaturation is compensated by sequence of magmatic crystallization and fractionation of aegirine, riebeckite, biotite, alkali feldspars and magnetite and the residual magma is saturated with quartz, feldspars, and magnetite / biotite [14, 15]. Concerned to the present study, initial crystallization of nepheline normative albite under progressively increasing $\mathrm{P}_{\mathrm{O} 2}, \mathrm{P}_{\mathrm{H} 2 \mathrm{O}}$ condition, the low viscous residual magma comprising of free circulating residual elements [21] is get enriched with Si. This is also more effective due to release of volatile fluids into the residual magma in a closed magmatic chamber during the course of crystallization of albite and galena. A negative correlation of $\mathrm{Al}$ against $\mathrm{Si}$ or $\mathrm{K}$ against $\mathrm{Na}$ indicates relatively progressive volatile enriched conditions with progressive decreasing of viscosity with free circulation of mineralizing fluids [8]. On comparison of $\mathrm{PbO}$ and $\mathrm{S}$ concentrations in albites and galena, there exists a linear trend of genetic relationship between galena and albite. $\mathrm{F} / \mathrm{Cl}$ ratio could be used as a degassing index. Fluorine could be a good tracer of the liquid phase and it is not affected by degassing processes [21]. It behaves as a strongly incompatible element in magma differentiation. Determination of incompatible elements and their ratios show genetic relationships between galena and its host mineral. High field strength elements and their ratios such as $\mathrm{Zr} / \mathrm{Hf}$ and $\mathrm{Nb} / \mathrm{Ta}$ and $\mathrm{Th}, \mathrm{Tb}$, and $\mathrm{Yb}$ reflect variability in primary mantle source and magmatic processes $[15,16] \cdot \mathrm{Pb} / \mathrm{Cu}$ and $\mathrm{Zn} / \mathrm{Cu}$ ratios in these minerals positively correlate with galena mineralization. $\mathrm{Zr} / \mathrm{Hf}$ and $\mathrm{Nb} / \mathrm{Ta}$ indicate highly fractionated residual fluids enriched with $\mathrm{Pb}$ and $\mathrm{S}$. Ratios of $\mathrm{F} / \mathrm{Cl}, \mathrm{Zr} / \mathrm{Hf}, \mathrm{Nb} / \mathrm{Ta}, \mathrm{Y} / \mathrm{Sc}, \mathrm{La} / \mathrm{Lu}, \mathrm{Ce} / \mathrm{Yb}, \mathrm{Yb} / \mathrm{Ta}, \mathrm{Pb} / \mathrm{Cu}, \mathrm{Pb} / \mathrm{Zn}$ indicate presence of oscillatory compositional variations from central portions to peripheral portions in the fragments of albitite or galena. The linear distribution of elements from silica undersaturated portion to silica oversaturated end indicates crystallization of galena and albite from low degree release of volatiles to high degree of release of volatiles to the residual magma during late magmatic crystallizations. A linear trend of magmatic crystallization of albite is seen against logarithmic distribution of orthoclase. Volatiles are expelled into the residual liquid fractions during crystallization of albite. Progressively extraction of $\mathrm{Al}, \mathrm{Na}$ and $\mathrm{K}$ by crystallization of nepheline normative albite depletes $\mathrm{Al}, \mathrm{Na}$, and $\mathrm{K}$ and enriches $\mathrm{Si}$ in the residual magma and silica oversaturated granitic residual magma injected as pegmatite veins in this carbonatite complex. The present study reveals that galena mineralization took place just after immiscible separation of sulphide phases and silicate phases but prior to initial crystallization of albite Tf3 at higher temperature at about $750^{\circ} \mathrm{C}$ and water pressure greater than $5 \mathrm{kbar}$. On further crystallization and differentiation, subsolidus albite and galena crystals trap more quantity of volatile constituents at their subsolidus crystal imperfections. The volatile depleted residual liquid rapidly consolidates 
as fine-grained aplitic albitite with characteristic allotriomorphic texture. A number of triangular, square and rectangular shaped crystal originated pits are seen galena. In albite voids at interstitial spaces found dislocation of substrate layers can accommodate significant volume of volatiles. Albite and galena formed at later stages contain more volatiles at their void spaces of crystal imperfections. Volatiles filled in void spaces of crystal imperfections play critical role on the increase of viscosity of residual magma and it depends upon the rate of cooling. The formation of silica saturated albite and galena is generally controlled by the enrichment of volatile constituents in the residual magma $[13,19,23,24]$. However, these variations are due to subtle physical and chemical gradients $[22,23]$ changes caused by turbulence in magmatic fluids and accommodation or capturing of elements during the course of crystallization of minerals in accordance with orientations of crystals and turbulent movements of mineralizing fluids to attain crystal-stabilization of these minerals during their growth. Though galena mineralization is limited to in the forms of droplets, pods and disseminations in albitite, the mineralization is intimately related with emplacement of ultramafic alkali carbonatite complex of Tiruppattur which is controlled by regional tectonic features. Zoned alkali carbonatite complex of Tiruppattur is emplaced in two adjacent structural basins bounded by NE-SW trending faults in a graben structure [10] bounded by deep faults of Peninsular India [26]. The graben lies within NE-SW trending Eastern Ghats Paleorift System extending over 3000 x $200 \mathrm{~km}$ from the Eastern Himalayan Syntaxis to Palghat Gap [3, 10, 26-28] and further extending through Arabian Sea. Though, the Eastern Ghats is considered to be a mobile belt comprising with ortho/clinopyroxene pyroxene granulite facies of rocks trending in NE-SW direction in the form of linear belts, it is bounded by NE-SW trending fault systems. Fermor correlated charnockitic region and non-charnockitic region separated by iron ore bodies subjected to fault deformations. The NE-SW trending Precambrian rift system is dissected by several cross-cutting rift systems such as E-W trending Dauki fault in fault bounded Brahmaputra valley, Narmada-Son, Damodar, Godavari, Attur, Cauvery, Vaigai grabens and presence of eastcoast parallel horst and graben structures onland and offshore regions. The block-faulted rift system comprises several anorogenic igneous bodies of charnockites, anorthosites and carbonatite alkali complexes (including Purulia carbonatite in West Bengal and Wah-Sung Valley carbonatites in Meghalaya) and volcanic lava flows derived from mantle source and caused separation of Indian plate. A new interpretation for pull-apart tectonic framework based on geophysical studies on the East Coast Margin of India is also supports this view [25-29]. Magma derived from low degree of partial melting of deep-seated source of the mantle horizon generally enriched with alkalies and volatile constituents.

\section{CONCLUSION}

Carbonatite complexes are often associated with deep main faults [10] extending to mantle horizon. The occurrences of many carbonatite alkaline complexes in the half graben of East-coast of Peninsular India, suggest that the Eastern Ghats Belt associated with Great Boundary Fault of the Precambrian terrain belong to a major rift system as that of Narmada-Son which is also associated with carbonatite complexes. They act as conduits of emplacements of ultramafic carbonatite-alkaline rocks. Geochemical studies of the carbonatite complex reveals that the magmatic rocks emplaced in both Sevvattur and Jogipatti basins were differentiated and fractionated from common parent magma with intermittent immiscible separation of carbonate and silicate liquids [11-15]. Though differentiated and fractionated rocks have varying chronological orders, their higher level emplacements in the ultamafic alkaline complex of Tiruppattur or the order of arrangement of individual mineral grains even in a single specimen abruptly varies, due to swirling currents and turbulence in the magmatic chamber or due to crystal field stabilization within a single mineral grains. The present study reveals that compositional variations are induced during packing of mineral grains within a large crystal during its growth even in nanometric scale which illustrates their stages of crystallization and compositional variation of the residual fluid / magma. The parent magma of this carbonatite complex would have maintained its low viscous state for a long period during the course of magmatic differentiation and fractionation till its final stage of complete solidification or consolidation. By studying an albite grain, the magmatic evolution from silica undersaturated stage to over-saturated end has been traced out in this paper.

\section{ACKNOWLEDGEMENTS}

The first author gratefully acknowledges Thiru. V. Gopal, Former State Geologist, Tamil Nadu State Department of Geology and Mining, Chennai-32, who showed disseminations of native copper, silver, galena, chalcopyrite, pyrite, bornite, covellite, chalcocite, azurite and malachite by breaking an ultrabasic nodule in a skarn rock in 1976. He also acknowledges Thiru. T. Ragavaaiah, Senior Technician for helping HR SEM EDAX analyses in the Department of Material and Metallurgical Engineering, Indian Institute of Technology, Chennai, 600036. The authors express their sincere thanks to an anonymous referee who made critical comments and suggestions to improve the quality of the manuscript. 


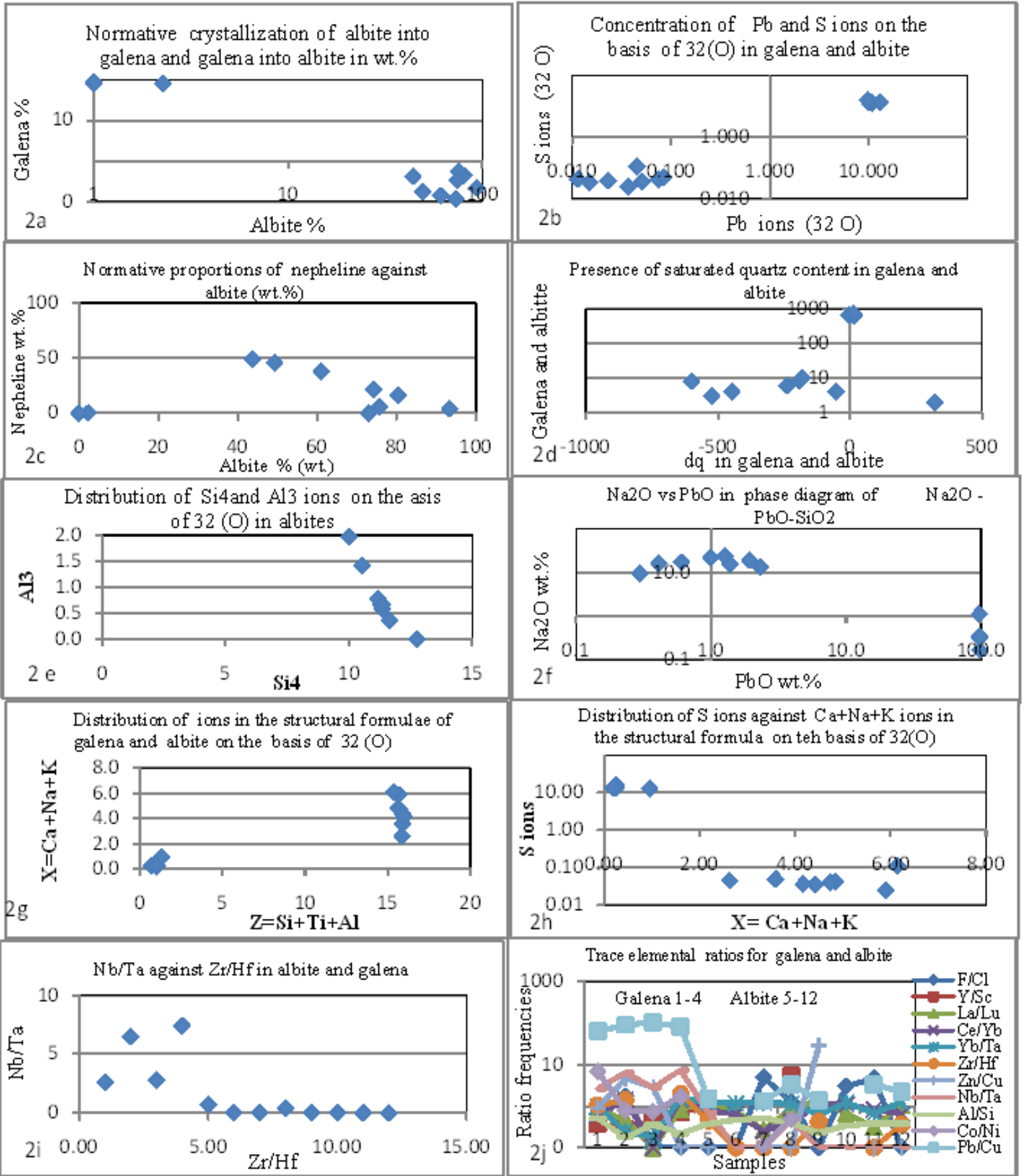

Figure 2 Co-variations of atoms showing a linear trend of magmatic crystallization of albite and associated galena. Subtle changes in chemical variations are due to turbulent movements and orientations of crystals during their crystal field stabilization. 

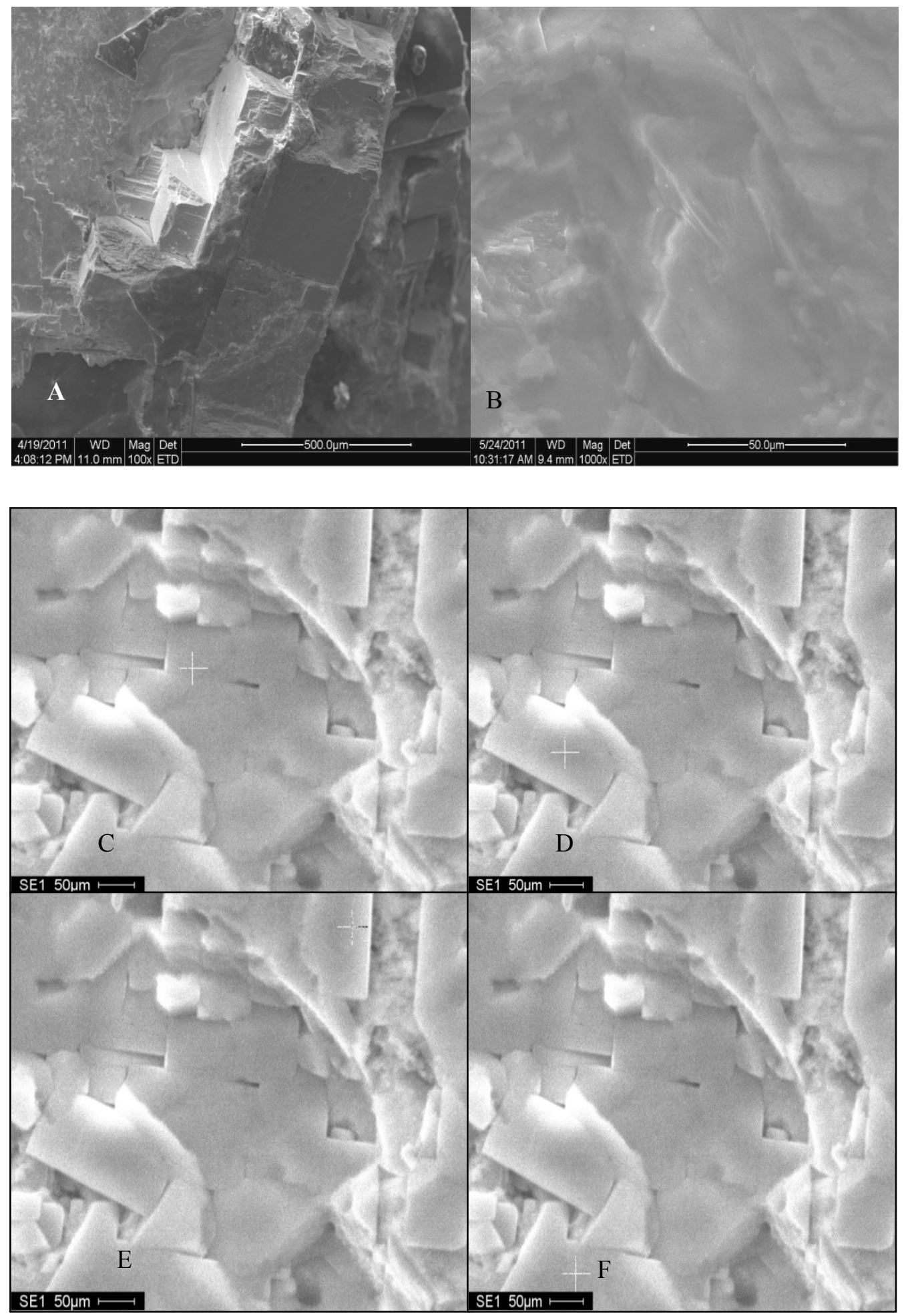

SEM Images A- Galena B- Albite C, D, E,F are sites of different galena crystals on which EDAX analyses are carried out from inner portion to outer portion in galena. Cubic, triangular and rectangular crystal oriented pits are seen in galena. It is inferred that these pits stored volatile matters during subsolidus crystallization of galena. 


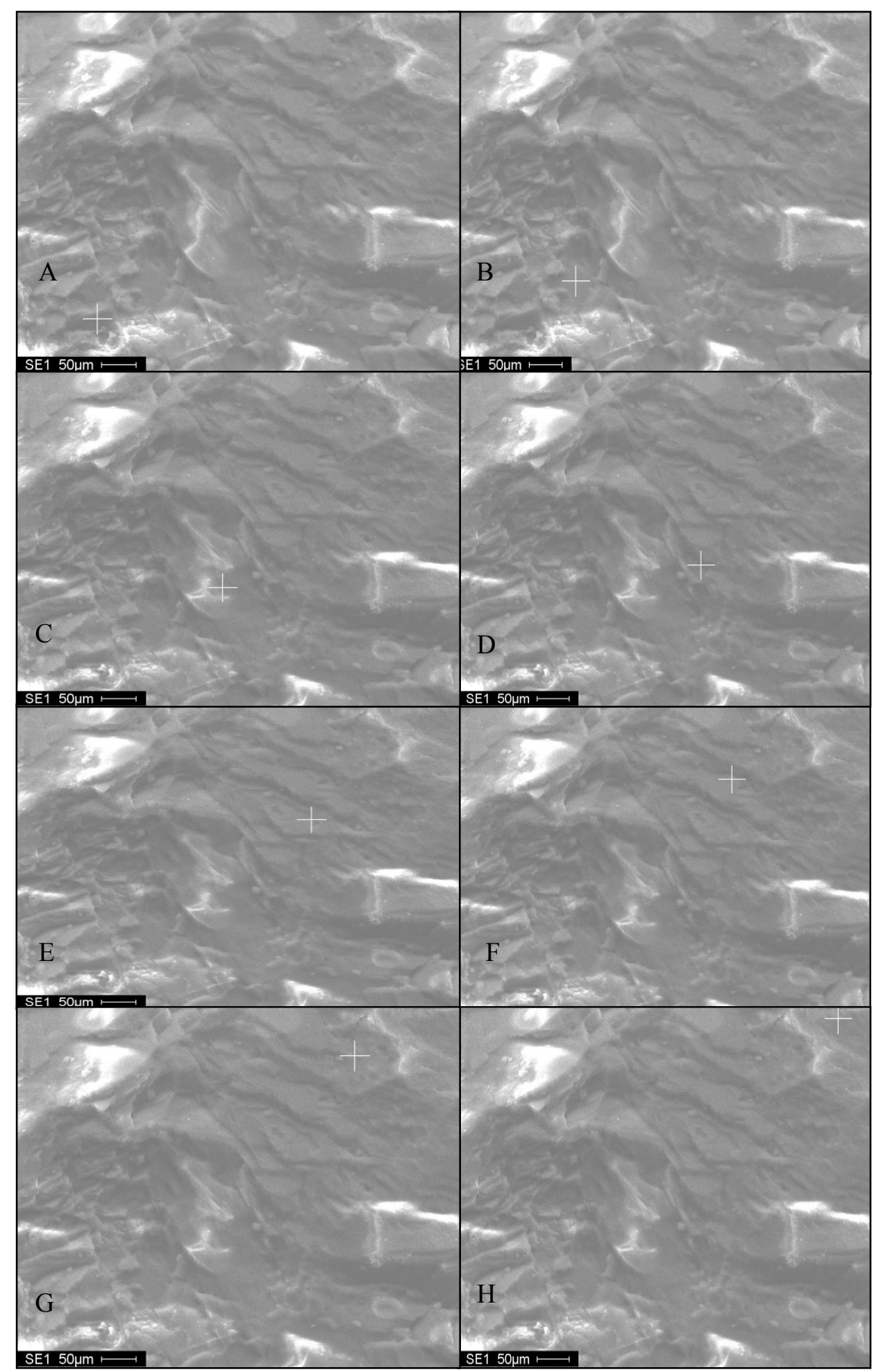

SEM Images -EDAX analyses were made from the inner (bottom) portion of a feldspar fragment towards its peripheral portion to study chemical compositional variations within different albite crystals within a single fragment $(2 \mathrm{mmx} 2 \mathrm{mmx} 1 \mathrm{~mm})$. The albite is the host mineral of galena. Significant amount of volatiles are stored in voids occurring at interstitial spaces of albite layers 


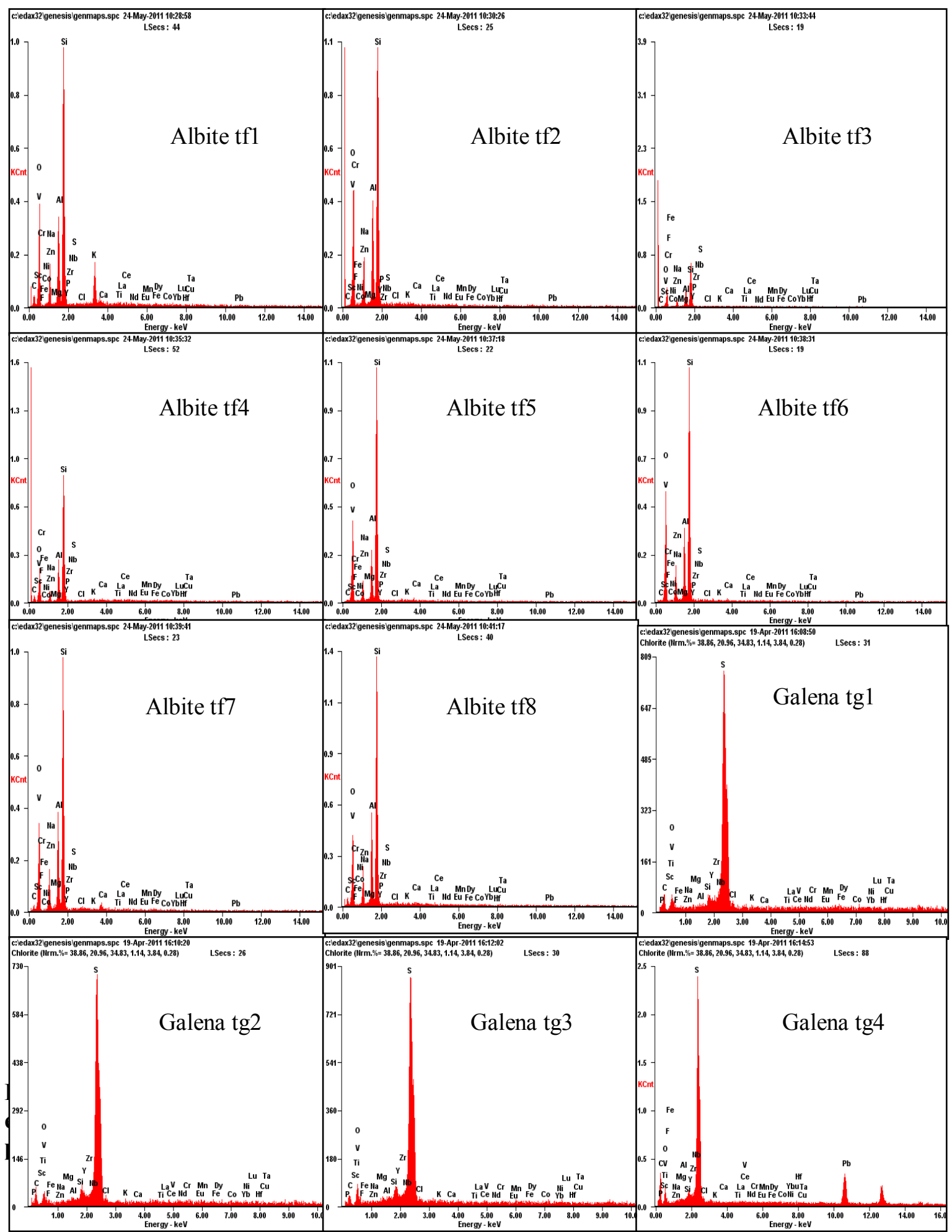

Elemental analyses of albite and galena samples in HR SEM scanning electron microscope attached with EDAX probe analyzer 


\section{References}

[1] E. Wm. Heinrich, Geology of Carbonatites, Rand McNally, Chicago University Press, Chicago, 1966

[2] L.S. Borodin, V. Gopal, V.M. Moralev, V. Subramanian, and V. Ponkikarov, Precambrian carbonatites of Tamil Nadu, J. Geol. Soc. of India, 1971, v. 12, pp.102-112

[3] R. Ramasamy, Geology of the area southwest of Tiruppattur, Tamil Nadu, India, Ph.D. Thesis, 1973. Univ. Madras 226p

[4] R. Ramasamy, Structure and Tectonics of carbonatite complex of Tiruppattur, Tamil Nadu, Current Trends in Geology, v.7, IV th IGC Proc. Today and Tomorrow's Printers \& Publishers, New Delhi, pp. 119-136

[5] N.K.N. Aiyengar, Minerals of Madras, Dept. of Industries and Commerce, Govt. of Tamil Nadu, Chennai, 1964

[6] S. Prasad, Molybdenum reserves remain untapped, The Hindu, Front Page Jan 3, 2006

[7] P.S. Rao, T.A. Selvan, S. Singanenjam, and M.Shanmugam, Molybdenum mineralization and carbonate-syenite complexes of Northern Tamil Nadu, National Seminar on Precambrian Geology, Abst. vol. 1990, 56p

[8] R. Ramasamy, Ultrabasic nodules in skarn rocks of Garigaipalli in carbonatite complex of Tiruppattur, Tamil Nadu- Group discussion, Bangalore, J. Geol. Soc. India, Sept, 1976, p. 5

[9] R. Ramasamy, Some aspects of alkaline rocks of Sevvattur, in carbonatite complex of Tiruppattur, Tamil Nadu, Group Discussion, J. Geol. Soc. India, Bangalore, Sept, 1976, p. 4

[10] J.C. Grady, Deep main faults in South India, J. Geol. Soc. India, v. 12, 1971, pp 56-62

[11] V. Subramanian, S.G. Viladkar, and R. Upendran, Carbonatite alkaline complex of Samalpatti, Dharmapuri District, Tamil Nadu, J. Geol. Soc. India, v. 19, 1978, pp. 206-216

[12] S. Saravanan, and R. Ramasamy, Geochemistry and petrogenesis of shonkinite and associated alkaline rocks of Tiruppattur carbonatite complex. Tamil Nadu, J. Geol. Soc. India v. 46, 1995, pp. 235-243

[13] R. Ramasamy, Ca-rich pyroxenes from the carbonatite complex of Tiruppattur, Tamil Nadu, Current Sci., 1986, 55, 981-984

[14] R. Ramasamy, SP. Subramanian, and R. Sundaravadivelu, Compositional variations of olivine in shonkinite and its associated ultrabasic rock from the carbonatite complex of Tiruppattur, Tamil Nadu, Current Sci., v. 99, 2010, pp1428-1433

[15] R. Ramasamy, Crystallization, fractionation and solidification of co-magmatic alkaline series sequentially emplaced in carbonatite complex of Tiruppattur, Tamil Nadu, India, Book on Crystallization- Science and Technology, Edrs Marcello Rubens, Barsi Andreeta, ISBN, pp. 535-564, $12^{\text {th }}$ Sept. 2012, INTECH, Austria

[16] M.J.K. Flohr and M. Ross, Alkaline igneous rocks of Magnet Cove Arkansas: Mineralogy and Geochemistry of syenites, Lithos, 1990, v. 26, 1-2 pp. 67-98

[17] W.A. Deer, R..A., Howie, and J. Zussman, An Introduction to the Rock Forming Minerals $2^{\text {nd }}$ edn, Pearson Prentice Hall, London 1992, 696p.

[18] R.S. Zeng, and W.S. Mackenzie, Preliminary report on the system $\mathrm{NaAlSiO}_{4}-\mathrm{KAlSiO}_{4}-\mathrm{SiO}_{2}-\mathrm{H}_{2} \mathrm{O}$ at $\mathrm{PH}_{2} \mathrm{O}=5 \mathrm{~kb}$ Scientia Sinica, Ser. B. 30, 1984, 198-211

[19] A. Rittmann, Stable Mineral Assemblage of Igneous Rocks, Springer-Verlag, Berlin, 1973, p.262

[20] F.V. Charkov, B.V. Lenin, and N.N. Obsyanikova, Minerals V. II, Handbook Phase Equilibrium diagrams, Science Publications, Acad. Sci., SSSR, 1974, d. 1306, p. 343

[21] D. Giordano, J.K. Russel, D.B. Dingwell, Viscosity of magmatic liquids : A Model, Earth and Planetary Science Letters, v. 271, 2008, 123-134

[22] Benoit Villemant and $\mathrm{G}$. Boudon, $\mathrm{H}_{2} \mathrm{O}$ and halogen $(\mathrm{F}, \mathrm{Cl}, \mathrm{Br})$ behaviour during shallow magma degassing processes, Earth and Planetary Science Letters, v. 168, 3-4, May, 1999, 271-286

[23] V.W. Lueth, P.K.M. Megaw, N.E. Pingitore, and P.C. Goodell, Systematic Variation in Galena Solid-Solution Compositions at Santa Eulalia, Chihuahua, Mexico, Economic Geology, 2000 v. 95, 8 No, 1673-1687, 2000

[24] K. Yagi, Petrochemical studies on the alkali rocks of the Morotu District, Sakhalin, GSA Bull., 1953, 64, 769-810

[25] R. Ramasamy, Presence of Eastern Ghats Paleorift System in the Peninsular India, Bull. Moscow State Univ., Geology, Ser 4. 1982a pp.32-37

[26] R. Ramasamy, Gabbroic anorthosite from Togamalai area, Coimbatore District, Tamil Nadu, Current Sci., v. 52,1983 pp $683-686$

[27] R. Ramasamy, Reactivation of Eastern Ghats Paleorift System during Tertiary Orogeny, Proc. Nat. Sem. Tertiary Orogeny, Banaras Hindu Univ., 1987, pp. 107-127

[28] R. Ramasamy, SP. Subramanian, and R. Sundaravadivelu, Carbonatite emplacement and localization of gas hydrates in the Ocean floors of Eastern Hemisphere, ISOPE, Ocean Mining Symposium, NIOT, Sept 2009

[29] K.S.R.Murthy, A.S. Subramanian, and Vandrapu Subrahmanyam, Tectonics of the Eastern Continental Margin of India -books. Google.co.in/booksisbn=817993408X, 2012, pp.184 